\title{
The differences response of massage types with variation massage pressure on running speed in POPDA Sleman athletics
}

\author{
Riza Galih Mustika Rini *, Eddy Purnomo \\ Universitas Negeri Yogyakarta. Jalan Colombo No. 1, Yogyakarta 55281, Indonesia. \\ *Corresponding Author E-mail: riza.galih2016@student.uny.ac.id
}

Received: November 16, 2020; Accepted: August 20, 2021; Published: September 25, 2021

\section{The differences response of massage types with variasion massage pressure on running speed in POPDA Sleman athletics}

\begin{abstract}
This study aims to improve the athlete's performance from the physiological aspect by knowing the differences in the response of sport massage and swedish massage with variations in pressure (light, medium, and heavy) on the hind limbs a $30 \mathrm{~m}$ running speed taken four times. This research is a quasiexperimental design, with the research subjects of POPDA Sleman athletic athletes with sample of 20 people. The sample was divided by matching pairs with the aim of both groups getting a balanced power. The treatments used are sports massage with movement manipulation (effleurage, tapotement, shaking/vibration) and swedish massage with movement manipulation (drainage, compression, tapotement, shaking/vibration) with pressure variation. The results showed that there were differences in the effect/good response of the type of sports massage treatment (group $x$ ) with moderate pressure. This is evidenced by the results of an increase in record time by an average of 0.36 seconds. Treatment of light pressure increased record time by an average of 0.28 seconds. Heavy pressure treatment increased record time by an average of 0.04 seconds. There is a difference in the effect/unfavorable response of the type of swedih massage treatment (group y) with all types of pressure, because it provides a decreased response time from pretest to posttest. It is proven by the decrease in the average time of 0.16 seconds on the light pressure treatment, the decrease in the average time of 0.24 seconds on the medium pressure treatment, and a decrease of 0.34 seconds on the heavy pressure treatment.
\end{abstract}

Keywords: running speed, sport massage, swedish massage, pressure massage

How to Cite: Rini, R. G. M., \& Purnomo, E. (2021). The differences response of massage types with variation massage pressure on running speed in POPDA Sleman athletics. Jurnal Keolahragaan, 9(2), 193-201. doi:https://doi.org/10.21831/jk.v9i2.35808

\section{INTRODUCTION}

Sports activities are often found in various places. Such as simple activities such as walking, jogging, or cycling around the house. There are also sports in fitness venues, clubs, and communities for various purposes. From the goal can be known the direction to be achieved, such as to get pleasure, fitness, and achievement. Performance sports are sports activities with the aim of achieving a better record of achievement from time to time, carried out by athletes with a gradual training process. Sport is one of the instruments in the context of achieving regional achievements. Especially in the Special Region of Yogyakarta (Daerah Istimewa Yogyakarta $=$ DIY) there is a forum that can accommodate student athlete perform competitions in various sports which are incorporated in a routine activity, namely the DIY Regional is Pekan Olahraga Pelajar Daerah (POPDA). POPDA is the most prestigious annual student multi event in each province. POPDA activities become a benchmark for the effectiveness of students' self-development in the field of sports through participation in certain sports. POPDA is also a benchmark for fostering regional student sports achievements by competing in many sports. Apart from being a unifying tool among students, POPDA aims to improve the problem solving, breeding, and coaching of talented athletes who are later expected to be able to excel at national, regional, and international levels (Suyatmo, 2019). 
Athletics is kind of the sports that is competed in every multi-event such as POPDA, besides that athletics is also the biggest contributor to medals in every multi-event because there are twelve (12) numbers being contested. Each district/city area always competes for victory and expects high achievement in the POPDA event. So that each region prepares the athletes seriously to face these big multi events. To prepare the athletes, each region forms a training center or athlete coaching which aims to foster and prepare athletes physically, psychologically, and materially.

The basic physical or biomotor component in general, what athletes need the most is speed in each sport. Speed is the time it takes to make an effort. According to Eddy Purnomo (2007, p. 30) "speed in short distance running is the result of strong and fast contractions of the muscles that are converted into smooth and efficient movements and are needed for runners to get high speed". According to Sukadiyanto (2011, p. 116) "speed is the ability of a muscle or a group of muscles to respond to stimuli in a short time". From the biomechanics aspect of speed, especially running, it is determined by the length of the steps and the frequency of steps. The optimal stride length is very influential on the physical character of the athlete and the speed of each step. It is influenced by strength, power, and mobility (IAAF, 2009, p. 5).

Efforts to improve athlete performance can be done from various aspects, including physical condition, technique, psychology, nutrition, competition strategy, and rest. In recent years, massage before sports activities has been increasingly developed to optimize the physiological, biological, and psychological performance of athletes (Arovah, 2009, p. 12). From the type of method, massage is very diverse, such as sports massage, Swedish massage, traditional massage, and various massages developed from other regions. Of the various massages available, there are two types of massage that have the same massage goal, namely sports massage and Swedish massage (Jusuf et al., 2020).

The use of massage can support physical performance as well as for other purposes such as minimizing the risk of injury, therapy, and injury rehabilitation, as well as negative impacts such as cramps and fatigue from exercise (Priyambada et al., 2018). According to the American Massage Therapy Association quoted from the journal Injury Prevention Indonesia Fitness Trainer Association, massage can improve performance, reduce pain, prevent injury, encourage focus, and shorten recovery time. The use of massage in the world of sports is very common, so many sports player use the services of a masseur to get massage treatment.

There are variations in pressure that cause different responses, pressure differences during massage have been shown to produce different behavioral and neurological effects such as stimulating innervation, especially peripheral nerves, to increase sensitivity to stimuli, increase muscle tension (tonus), and elasticity to enhance muscle work power (Priyonoadi, 2011, p. 6). Everyone has a different tolerance for massage pressure. (Ingraham, 2020) "Pressure that is comfortable enough for one person will actually cause severe pain and emotional stress in another. So that the therapist communicates, respects, and is attentive to the patient. Despite all the considerations, there needs to be communication about pressure." The amount of pressure a person needs varies, depending on each person and depending on the person's sense/ability to a pressure on the manipulated body part (Paradise Spa, 2017). For this reason, it is important to communicate with the therapist during massage and be able to advise whether a therapist is not using enough pressure or if they are using too much pressure and causing pain. In a study by (Field et al, 2006, p. 576) pregnant women who received moderate pressure massage were shown to be happier, they received better scores in the orientation, motor, stimulation, and depression groups of the Brazelton scale than pregnant women who received a light massage. In moderate pressure massage, the physiological evidence of a relaxation response was less significant than in subjects receiving light massage. Massage helps increase the elasticity of the tissues.

Massage treatment before exercise can provide benefits, in addition to avoiding injury, it can also help muscles to improve their performance optimally. The benefits of massage can accelerate blood circulation, stimulate nerves, increase muscle tension, increase elasticity. The type of massage treatment and variations in massage pressure can cause different responses. There was a journal from Sports Science and Medicine in 2008 by Ramiz Arabaci which showed the effect of massage with a long duration had the effect of decreasing acceleration, sprint time, and worsening vertical jump. In 2010, Fletcher investigated the effects of massage, dynamic warm-up, and intervene massage combined with dynamic warm-up on 20-m sprint performance in male college rugby, soccer, and basketball athletes showing faster sprint times than the intervention massage. (Ryan N. Moran 2017, p. 
3) in his research showed that there was a comparison of increasing speed between giving massage and warming up before running.

In connection with this and the results of observations with the team and administrators of the Sleman Athletic Association (Persatuan Atletik Seluruh Indonesia = PASI) for POPDA, the researchers found that there was a lack of information on the application of massage specifically, such as the type of massage (sport massage and Swedish massage) and variations in pressure (light, medium, and heavy) to improve performance in POPDA Sleman athletic athletes.

\section{METHODS}

The method used is a quasi-experimental method design. This quasi-experimental design has a control class but doesn't fully function to control external variables that affect the implementation of the experiment. Quasi experiment is used because in reality it is difficult to get a control group used for research. The research method used in this study is a $2 \times 3$ factorial design. Each factor consists of three levels, using the initial test (pre-test) and the final test (post-test). Data collection was carried out in February 2020 at the Tridadi Football and Athletics Stadium, Sleman. This study aims to compare two types of massage (sport massage and swedish massage) with three different pressures (light, medium, and heavy) on research subjects. The subjects in this study were POPDA athletic athletes who actively exercise with PASI Sleman at least three times a week. The implementation of data collection for running speed records before and after being given a sport massage and swedish massage as well as the difference in pressure on the back of the legs for each athlete. The test in this study was a test of taking the speed of a $30 \mathrm{~m}$ running standing start. This test technique is used to measure the results of the athlete's running speed. Research procedure:

All athletes who were tested (respondents) before being given treatment were recorded when they ran $30 \mathrm{~m}$ from standing position (pretest);

1. Record the results on the data blank;

2. Of all the athletes who have done the pretest, then they are divided into two groups by matching pairs to determine group $\mathrm{X}$ and group $\mathrm{Y}$. Group $\mathrm{X}$ is for athletes who will be given sport massage treatment on the back legs and $\mathrm{Y}$ for athletes will be given Swedish massage treatment on limbs;

3. Each group gets massage manipulation according to their group, as follows:

Tabel 1. Massage Treatment

\begin{tabular}{cll}
\hline No & \multicolumn{1}{c}{ Sport Massage } & \multicolumn{1}{c}{ Swedish Massage } \\
\hline 1 & Effleurage (2 Minute) & Drainage (2 Minute) \\
2 & Tapotement (1-1,5 Minute) & Compression (1-1,5 Minute) \\
3 & Shaking/vibration (2 Minute) & Tapotement (1-1,5 Minute) \\
4 & Effleurage (2 Minute) & Shaking/vibration (2 Minute) \\
\hline \multicolumn{2}{c}{7 Minute } & 7 Minute \\
\hline
\end{tabular}

One series of massage numbers 1 to 4 is carried out on the right leg first according to the duration in the table, then replace it on the left leg;

1. Treatment is given with three types of pressure (mild, moderate, and severe). For light pressure, athletes are given movements such as rubbing. At moderate pressure, the athlete is given a pressing movement using hand strength, while for heavy pressure, the athlete is given a pressing movement using the push/strength of the massager's body;

2. Each treatment with a different pressure is then tested (posttest).

The data analysis technique used in this study was SPSS 20, namely the two-way Analysis of Variance (ANAVA) at a significance level of $=0.05$. Furthermore, to compare the mean pairs of treatments used the Newman Keuls Range test (Sudjana 2005, p. 36-40). Considering that research data analysis was carried out using ANAVA, before arriving at the use of ANAVA, it is necessary to test requirements, which include: (1) normality test and (2) homogeneity test of variance. The instrument is a $30 \mathrm{~m}$ running test with standing start. The test is carried out on a straight line, the starting line is taken $30 \mathrm{~m}$ from the finish line. The data collection technique for massage pressure and to record and measure the results of the run time is that the research subject fills in the personal data that has been provided in the form of an observation sheet by filling in the personal data and circling the number according to the predetermined group. Documentation techniques are used to strengthen 
the data that has been obtained during observation. Documentation techniques can be in the form of notes, archives, videos, and photos. The test technique in this study was a test of taking the speed of a $30 \mathrm{~m}$ running standing start. This test technique is used to measure the results of the athlete's running speed.

\section{RESULTS AND DISCUSSION}

The data for treatment $\mathrm{X}$ was taken in four stages, namely the first stage in the pretest three times and the next three stages in the posttest three times each. The pretest was measured before the subject received the treatment, the first posttest was measured after the subject received the treatment with mild pressure, the second posttest after the subject received the moderate pressure treatment, and the third after the subject received the heavy pressure treatment. There is an increase in time (better) on the second posttest (moderate pressure).

Tabel 2. The Best Time, Average, Standart Deviasi Treatment $\mathrm{X}$

\begin{tabular}{clrccc}
\hline \multirow{2}{*}{ No Name } & \multirow{2}{*}{ Pretest } & \multicolumn{3}{c}{ PostTest } \\
\cline { 3 - 6 } & & 4,58 & 4,49 & 4,43 & 4,61 \\
\hline 1 & Melianus Tatogo & 4,99 & 4,97 & 4,89 & 5,07 \\
2 & Jesica Putri Larasati & 5,22 & 4,99 & 4,94 & 5,13 \\
3 & Riska Norma Saputi & 5,32 & 5,02 & 5,03 & 5,21 \\
4 & Sha Bran Juhaida & 5,39 & 5,36 & 5,31 & 5,69 \\
5 & Wira Yuli S & 4,61 & 4,44 & 4,37 & 4,63 \\
6 & Agung Budi S & 4,80 & 4,48 & 4,44 & 4,84 \\
7 & Mahendra & 5,73 & 5,17 & 5,11 & 5,61 \\
8 & Annisa Gustin Magdalena & 5,96 & 4,96 & 4,69 & 5,21 \\
9 & Jullio Caesar C Iki & 4,42 & 4,37 & 4,23 & 4,61 \\
10 & Whenta Aditya Mulya & 5,10 & 4,82 & 4,74 & 5,06 \\
\hline \multicolumn{2}{c}{ SD } & 0,51 & 0,34 & 0,36 & 0,39 \\
\hline
\end{tabular}

Table 2 show the best time records for each subject and the average for each test. The average pretest time was 5.10 seconds, while the posttest with light pressure had an average time of 4.82 seconds, which means that the posttest with light pressure was better than the prettest. Posttest with medium pressure has an average time of 4.74 seconds. Posttest record time with heavy pressure is 5.06 seconds. From the data presented above, it can be concluded that respondents in the treatment $\mathrm{x}$ group on the medium pressure posttest had the best time compared to the pretest, light pressure posttest and heavy pressure posttest. So the treatment $\mathrm{x}$ given a better effect on the respondents.

Grafik 1. Average Times Treatment $\mathrm{X}$

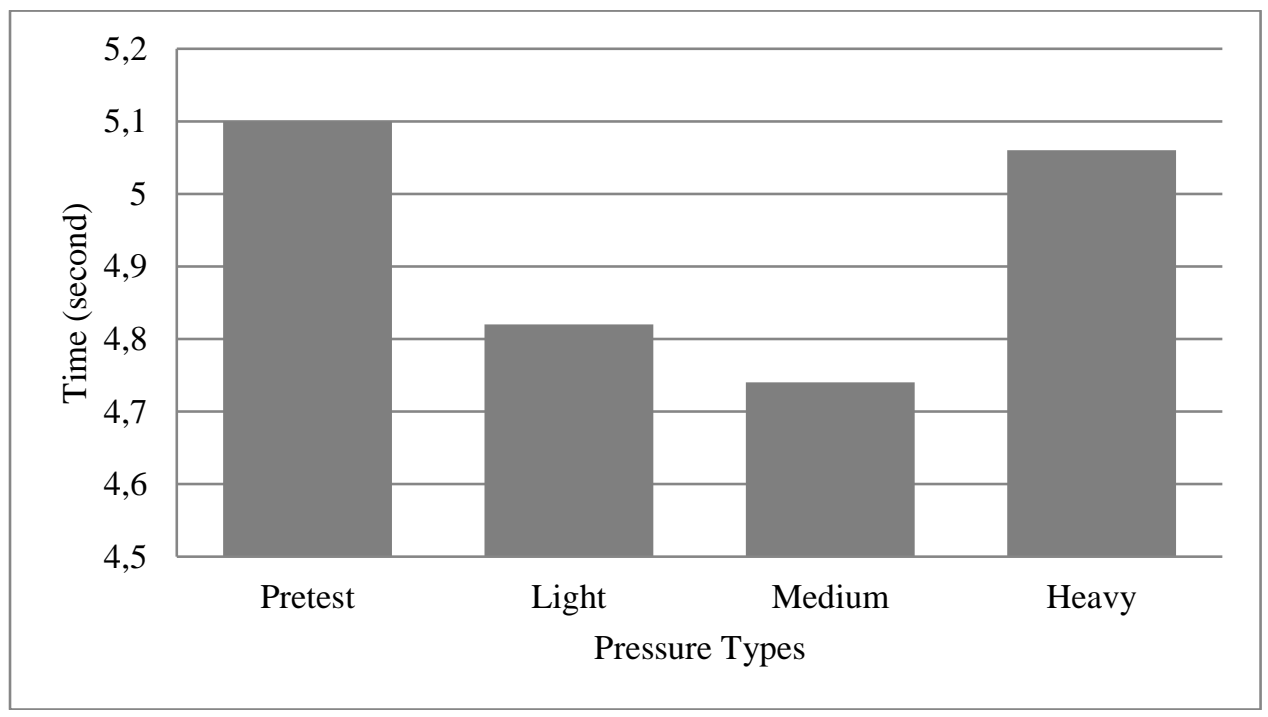

The data for treatment $\mathrm{X}$ was taken in four stages, namely the first stage in the pretest three times and the next three stages in the posttest three times each. The pretest was measured before the 
subject received treatment. The first posttest was measured after the subject received treatment with mild pressure, the second posttest after receiving moderate pressure treatment, and the third after receiving heavy pressure treatment. There is a decrease in time in the first, second, and third posttest.

Tabel 3. Best Time, Average, and Standard Deviasi Treatment $\mathrm{Y}$

\begin{tabular}{clcccc}
\hline \multirow{2}{*}{ No Name } & \multirow{2}{*}{ Pretest } & \multicolumn{3}{c}{ PostTest } \\
\cline { 4 - 6 } & & 4,97 & Light & Medium & Heavy \\
\hline 1 & Reza Arisandi W & 4,44 & 4,11 & 5,31 & 5,50 \\
2 & Ahmad Rifai & 5,25 & 5,41 & 5,69 & 4,74 \\
3 & Dian Kurniasari & 4,88 & 5,02 & 5,08 & 5,12 \\
4 & Mutiara O. Al-Pasha & 4,38 & 4,54 & 4,63 & 4,77 \\
5 & Fitria Astuti & 4,66 & 4,57 & 4,59 & 4,72 \\
6 & Ihtiar Wahyu B & 4,31 & 4,65 & 4,69 & 4,72 \\
7 & Arma Yudha & 4,79 & 5,14 & 5,17 & 5,24 \\
8 & Amanda Masruroh & 5,24 & 5,40 & 5,54 & 5,56 \\
9 & Prabayu Ajeng S & 4,75 & 4,75 & 4,87 & 4,98 \\
10 & Ilham Ahmad & 4,76 & 4,92 & 5,00 & 5,10 \\
\hline & $\bar{X}$ & 0,33 & 0,34 & 0,36 & 0,37 \\
\hline
\end{tabular}

Table 3 the data showing the best records of each subject and the average of each test. The average pretest time was 4.76 seconds, while the posttest with light pressure had an average time of 4.92 seconds, which means that the posttest with mild pressure was longer than the prettest. Posttest with medium pressure has an average time of 5.00 seconds. Posttest record time with heavy pressure is 5.10 seconds. From the data presented above, it can be concluded that respondents in the treatment group y in the pretest had the best time compared to the posttest with mild, moderate, and severe pressure. So the treatment y given did not give a better effect on the respondents.

Grafik 2. Average Time Treatment Y

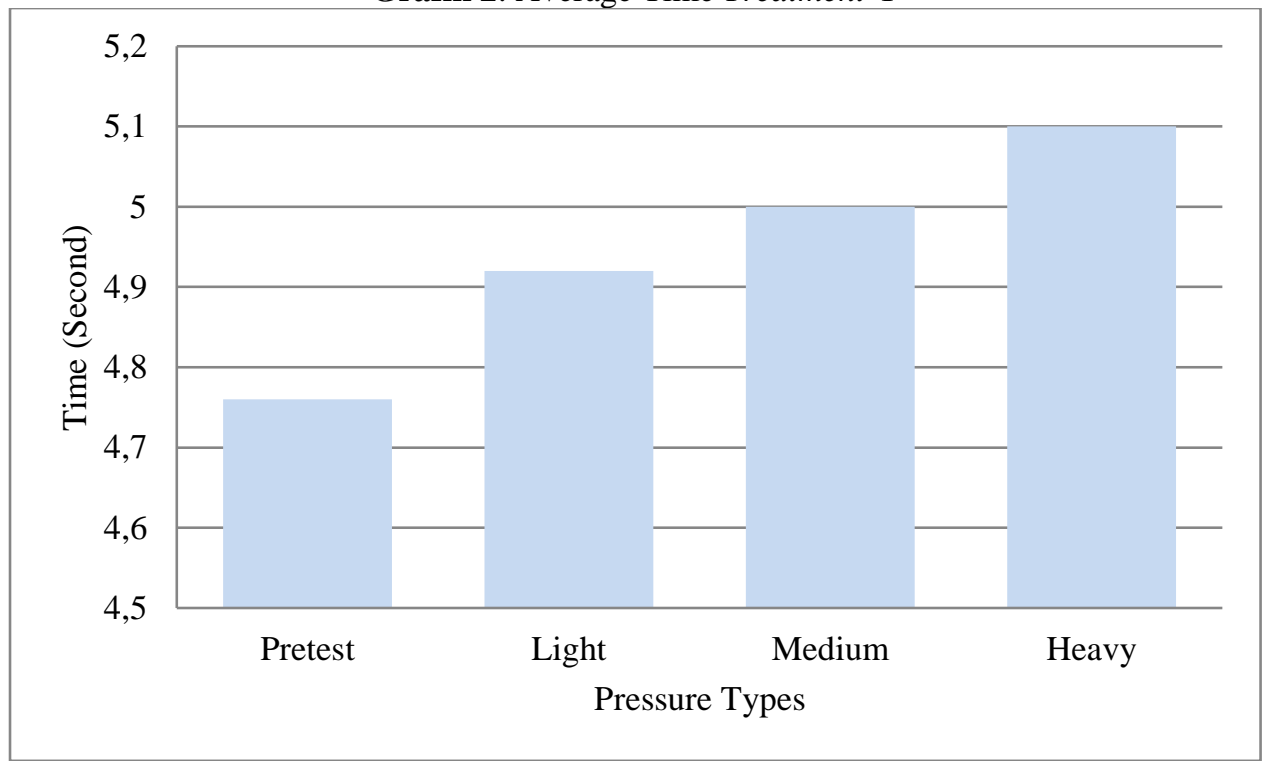

Massage pressure greatly affects the athlete's speed results, because muscles can respond to different types of pressure. Pressure that is too heavy actually causes a relaxing effect (Arabaci, 2008). Deep or heavy pressure is best used when athletes are finished with activities and for athletes in recovery and after strenuous exercise (Bridges and Roos, 2014). The time or duration of massage also affects muscle work. The recommended duration before sports activities with the aim to improving athlete performance is 10 to 12 minutes. In general, sports massage can provide measurable changes in anatomical status, muscle tissue, and improvements in stride length. As well as providing beneficial support to athletes for athlete performance and general function (Wilson, 2002). The swedih massage treatment reduces the rate of reaction, but has a positive effect on flexibility (Arabaci, 2008). Massage 
treatment that causes a relaxing effect is not recommended for the warm up process, because it will reduce the reaction speed.

An athlete's running speed cannot be separated from the combination of leg swing length and number of steps (Emral 2017, p. 181). Speed is also a contraction of the muscles in the legs, so strong and flexible muscles provide great support for a sprint athlete's speed. According to Emral (in Bompa, 1994) several factors that affect speed include: reaction time, strength, technique, muscle elasticity.

Massage is one way to increase muscle elasticity, so massage before sports activities is increasingly being developed to optimize athlete performance (Arovah 2009, p. 12). The types of massage that are most often used in the world of sports are sports massage and swedish massage. The purpose of this study was to determine the difference in the effect of sport massage treatment and swedish massage treatment with variations in pressure (light, medium, and heavy) on the back of the leg on the running speed of POPDA Sleman athletic athletes. The main findings of this study are:

In the comparison of pretest and posttest giving sport massage with light pressure, a significant value $=0.000<=0.05$, it shows that there is a difference or there is a significant effect on the provision of sports massage treatment between the pretest (running speed) and the posttest with light pressure (better time records) from posttest. In the comparison of pretest and posttest giving sport massage with medium pressure, a significant value $=0.000<=0.05$ indicates that there is a difference or there is a significant effect on the provision of sports massage treatment between the pretest (running speed) and the posttest of medium pressure (better time records) from posttest and light pressure). In the comparison of pretest and posttest giving sport massage with significant heavy pressure $=0.867>=0.05$, it shows that there is no significant effect on giving sports massage treatment between pretest (running speed) and heavy pressure posttest (time record is the same or decreased from posttest). These results are statistical results of the pretest and posttest time records after sport massage treatment was carried out with light, medium, and heavy pressure. Based on these results, the best time record is shown in the second posttest or after the athlete gets a medium pressure sports massage treatment.

In the provision of swedish massage treatment, there is a comparison between the pretest and posttest of light pressure with the results of a significant value $=0.000<=0.05$ indicating that there is a difference or there is a significant effect on the provision of swedish massage treatment between the pretest (running speed) and the posttest of light pressure (record time decreased from the pretest).

In the comparison of pretest and posttest giving Swedish massage with medium pressure, a significant value $=0.000<=0.05$ indicates that there is a difference or there is a significant influence on the provision of Swedish massage treatment between the pretest (running speed) and the posttest of medium pressure (time records decrease more from posttest and light pressure). In the comparison of pretest and posttest giving swedish massage with significant heavy pressure $=0.000<=0.05$, it shows that there is a difference or there is a significant effect on giving swedish massage treatment between the pretest (running speed) and the posttest heavy pressure (time record is the most decreased from posttest). The results above are statistical results from the pretest and posttest time records after the Swedish massage treatment was carried out with light, medium, and heavy pressure. Based on these results, the best record time is shown in the pretest, which means that the Swedish massage treatment did not give better results.

Tabel 4. Best Time Comparison Result

\begin{tabular}{ccccccccc}
\hline \multirow{2}{*}{ Massage Pressure } & \multicolumn{4}{c}{ Treatmen X } & \multicolumn{4}{c}{ Treatment Y } \\
\cline { 2 - 9 } & Pretest & Posttest & Second & $\%$ & Pretest & Posttest & Second & $\%$ \\
\hline Light & 5,1 & 4,82 & 0,28 & $5 \%$ & 4,76 & 4,92 & $-0,16$ & -3 \\
Medium & 5,1 & 4,74 & 0,26 & $7 \%$ & 4,76 & 5 & $-0,24$ & -5 \\
Heavy & 5,1 & 5,06 & 0,04 & $1 \%$ & 4,76 & 5,1 & $-0,34$ & -7 \\
\hline
\end{tabular}

Tabel 5. Significance Result of Increase/Decrease Time

\begin{tabular}{cclccc}
\hline No & Massage Types & Intensity & Increase $\%$ & Significance & Information \\
\hline \multirow{2}{*}{1} & \multirow{2}{*}{$\begin{array}{c}\text { Sport } \\
\text { Massage }\end{array}$} & Light & 5 & 0.00 & Increase Significance \\
\cline { 3 - 6 } & & Medium & 7 & 0.00 & Increase Significance \\
\cline { 3 - 6 } & \multirow{2}{*}{2} & Sweavy & 1 & 0.00 & Increase Significance \\
\hline \multirow{2}{*}{2} & Swedish & Light & -3 & 0.00 & DecreaseSignificance \\
\cline { 3 - 6 } & Massage & Medium & -5 & 0.00 & DecreaseSignificance \\
\cline { 3 - 6 } & & Heavy & -7 & 0.00 & DecreaseSignificance \\
\hline
\end{tabular}


Tables 4 and 5 show the results of the increase and decrease time in seconds taken from the best overall posttest results and percentages. In treatment $\mathrm{X}$ the highest increase was $7 \%$ at medium pressure and in treatment $\mathrm{Y}$ there was a negative result or sign which means that time has decreased. The most significant decrease was found in treatment $\mathrm{Y}$ with heavy pressure.

Grafik 5. Result of Comparison Average Time Sport Massage

(Treatment $\mathrm{X}$ ) and Swedish Massage (Treatment Y)

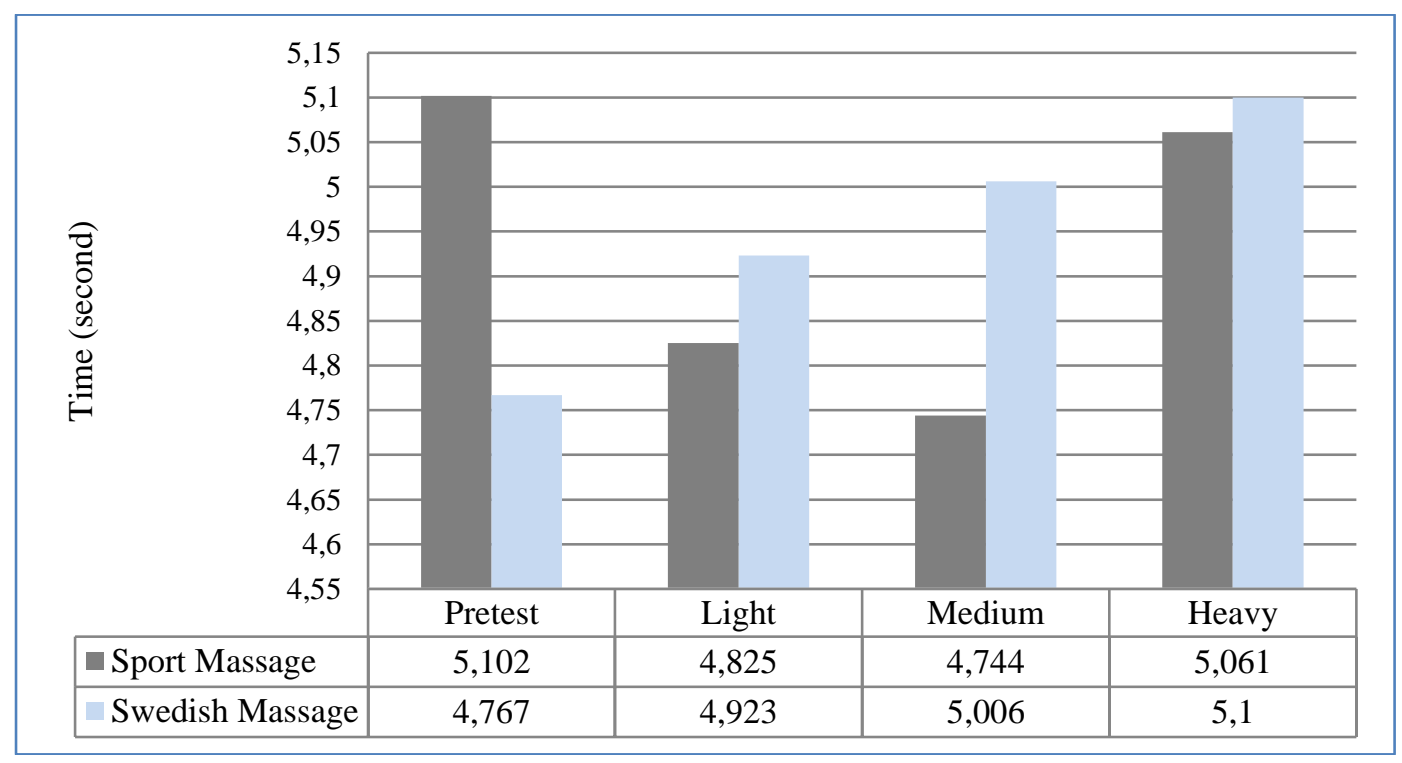

From the results of the graph above, it shows that the best time record was in the second posttest from the $\mathrm{X}$ treatment group or after the athlete received a medium pressure sport massage treatment. Meanwhile, the longest time was recorded in the third posttest from the treatment group Y or after the athlete received the Swedish massage with heavy pressure.

Massage pressure greatly affects the athlete's speed results, because muscles can respond to different types of pressure. Pressure that is too heavy actually causes a relaxing effect (Arabaci, 2008). Deep or heavy pressure is best used when athletes are finished with activities and for athletes in recovery and after strenuous exercise (Bridges and Roos, 2014). The time or duration of massage also affects muscle work. The recommended duration before sports activities with the aim of improving athlete performance is 10 to 12 minutes. In general, sports massage can provide measurable changes in anatomical status, muscle tissue, and improvements in stride length. As well as providing beneficial support to athletes for athlete performance and general function (Wilson, 2002). The swedih massage treatment reduces the rate of reaction, but has a positive effect on flexibility (Arabaci, 2008). Massage treatment that causes a relaxing effect is not recommended for the heating process, because it will reduce the reaction speed.

Researchers strive to fulfill all the conditions required, but that does not mean this research is without weaknesses and shortcomings. To get better research results, the number of subjects should be more, the need to pay attention to other supporting factors.

\section{CONCLUSION}

From the results of research that has been carried out by providing sports massage and Swedish massage treatments with various types of pressure (light, medium, and heavy), there are several conclusions including sports massage treatments with light, medium, and heavy pressure types that have an effect/response to increase time significantly. Evidenced by the average time at light pressure of 0.28 seconds, medium pressure with an average time of 0.36 seconds, and for heavy pressure with an average time of 0.04 seconds. Then for the Swedish massage treatment with all types of pressure (light, medium, and heavy) it actually gives a significant decrease in the effect/response time, because it actually increases the relaxation effect. Proven at light pressure with a record time of 0.16 seconds, at medium pressure with an average time of 0.24 seconds, and for heavy pressure with an average time 
of 0.34 seconds. The sport massage treatment with medium pressure gave the best effect/response, as evidenced by the results of the most improved/best time records.

\section{REFERENCES}

Arabaci, R. (2008). Acute Effects of Pre-event Lower Limb Massage on Explosive and High Speed Motor Capacities and Flexibility. Journal of Sports Science and Medicine, 7(4), 549-555.

Arovah, N. (2010). Masase dan Prestasi Atlet. Jurnal Olahraga Prestasi, 6(2), 116-122.

Benjamin, P. J., \& Lamp, S. P. (1999). Understanding Massage. In Transactions of the Institutions of Mining and Metallurgy, Section B: Applied Earth Science (Vol. 108, Issue JANUARY-APRIL). https://www.scopus.com/inward/record.uri?eid=2-s2.00033305399\&partnerID $=40 \&$ md5=cf615d8eed307b702573ec61417713b8

Best, T. M., Hunter, R., Wilcox, A., \& Haq, F. (2008). Effectiveness of Sports Massage for Recovery of Skeletal Muscle from Strenuous Exercise. Clinical Journal of Sport Medicine, 18(5), 446460.

Bridges, E., \& Roos, K. (2014). The Impact of Massage on Athetic Performance for Runners. CWHP Health \& Fitness Journal, 1-10.

Candra, A. R. D. (2016). Pembinaan Prestasi di Pusat Pendidikan dan Latihan Olahraga Pelajar (PPLP) Provinsi Jawa Tengah. ACTIVE: Journal of Physical Education, Sport, Health and Recreation, 5(2), 47-52.

Di Prampero, P. E., Fusi, S., Sepulcri, L., Morin, J. B., Belli, A., Antonutto, G., Prampero, P. E., Fusi, S., Sepulcri, L., Morin, J. B., Belli, A., \& Antonutto, G. (2005). Sprint Running: A New Energetic Approach. Journal of Experimental Biology, 208(14), 2809-2816. https://doi.org/10.1242/jeb.01700

Diego, M. A., \& Field, T. (2009). Moderate Pressure Massage Elicits a Parasympathetic Nervous System response. International Journal of Neuroscience, 119(5), 630-638. https://doi.org/10.1080/00207450802329605

Ermral, E. (2017). Pengantar Teori dan Metodologi Pelatihan Fisik. Kencana.

Faruq, M. M. (2008). Meningkatkan Kebugaran Tubuh Melalui Permainan dan Olahraga Sepak Bola. Surabaya: PT Gramedia Widiasarana Indonesia.

Fletcher, I. M. (2010). The Effects of Precompetition Massage on the Kinematic Parameters of 20-m Sprint Performance. The Journal of Strength \& Conditioning Research, 24(5), 1179-1183.

Goats, G. C. (1994). Massage The Scientific Basis of an Ancient Art: Part 2. Physiological and Therapeutic Effects. British Journal of Sports Medicine, 28(3), 153-156.

Graha, A. S. (2012). Medikora Vol. VIII, No 2 April 2012 Manfaat Terapi Masase Frirage dan Stretching dalam Penanganan Cedera pada Atlet Olahraga Beladiri. VIII(2).

Hermawan, S. (2015). Perbandingan Pengaruh Sport Massage dan Swedish Massage Terhadap Perubahan Denyut Nadi dan Frekuensi Pernafasan. Yogyakarta, Universitas Negeri Yogyakarta.

Hidayat, S. (2014). Pelatihan Olahraga Teori dan Metodologi. Yogyakarta: Graha Ilmu, 47-54.

Idris, I. (2016). Fisiologi Otot Rangka. Makassar: Universitas Hasanddin Makassar, 3-6.

Indonesia, P. M. P. N. R. (2015). Nomor 22 Tahun 2006. Tentang Standar Isi Untuk Satuan Pendidikan Dasar Dan Menengah.

Jusuf, J. B. K., Raharja, A. T., Mahardhika, N. A., \& Festiawan, R. (2020). Pengaruh Teknik Effleurage dan Petrissage Terhadap Penurunan Perasaan Lelah Pasca Latihan Pencak Silat. Jurnal Keolahragaan, 8(1), 1-8. https://doi.org/10.21831/jk.v8i1.30572 
Marani, I. N. (2016). Hubungan Kecepatan Reaksi dan Daya Ledak Otot Tungkai Otot Tungkai Terhadap Akselerasi 30 Meter Pada Lari Cepat 100 Meter Mahasiswa Fakultas Ilmu Keolahragaan Universitas Negeri Jakarta. 105-115.

Maughan, R. J., Depiesse, F., \& Geyer, H. (2007). International Association of Athletics Federations. The Use of Dietary Supplements by Athletes. J Sports Sci, 25(suppl 1), S103-S113.

Moraska, A. (2005). Sports Massage: A Comprehensive Review. Journal of Sports Medicine and Physical Fitness, 45(3), 370-380.

Ostrom, K. (1912). Massage and the Original Swedish Movement. The American Journal of Nursing, 12(10), 852. https://doi.org/10.2307/3404775

Paine, T. (2015). The Complete Guide to Sports Massage. Bloomsbury Publishing.

Priyambada, G., Raharja, A. T., \& Putra, F. (2018). Persepsi dan Minat Pelatih Olahraga Sekolah Khusus Olahraga Internasional Terhadap Sport Massage. 6(1), 77-86.

Purnomo, E. (2007). Pedoman Mengajar Dasar Gerak Atletik. Yogyakarta: Universitas Negeri Yogyakarta.

Rayhan, M., Putu, N., \& Wijayanti, N. (n.d.). Pengaruh Latihan Sprint 30 Meter Terhadap Kecepatan Lari pada Pemain Sepakbola di SSB Pekanbaru City Soccer School. 1-11.

Saputro, Y. A. (n.d.). Pengaruh Jenis Massage Terhadap Kelelahan Atlet Bulutangkis Ditinjau Dari Perbedaan Jenis Kelamin. 36, 25-36.

Sudjana, N. (2014). Penilaian Hasil Proses Belajar Mengajar.

Sugiyono, P. (2011). Metodologi Penelitian Kuantitatif Kualitatif dan R\&D. Alpabeta, Bandung.

Suharjana, S. (2013). Analisis Program Kebugaran Jasmani pada Pusat-pusat Kebugaran Jasmani Di Yogyakarta. Medikora, 11(2).

Sukadiyanto \& Muluk, D. (2011). Pengantar Teori dan Metodologi Melatih Fisik. Bandung: Lubuk Agung.

Suryobroto, A. S. (2004). Sarana dan Prasarana Pendidikan Jasmani di Sekolah Dasar. Diktat. Yogyakarta: FIK UNY.

Wilson, J. (2002). The Effects of Sports Massage on Athletic Performance and General Function. In Massage Therapy Journal (Vol. 41, Issue 2, pp. 90-101). 